\title{
Hemovigilance and patient safety: analysis of immediate transfusion reactions in elderly
}

\author{
Hemovigilância e segurança do paciente: análise de reações transfusionais imediatas em idosos
}

Hemovigilancia y seguridad del paciente: análisis de reacciones de transfusión inmediata en ancianos

'Secretaria de Estado de Saúde do Distrito Federal. Brasília, Distrito Federal, Brazil.

"Escola Superior de Ciências da Saúde. Brasília, Distrito Federal, Brazil.

How to cite this article: Sobral PAS, Göttems LBD, Santana LA. Hemovigilance and Patient Safety: Analysis of Immediate Transfusion Reactions

in Elderly. Rev Bras Enferm.2020;73(Suppl 3): e20190735. doi: http://dx.doi.org/10.1590/0034-7167-2019-0735

Corresponding author:

Paola Almeida dos Santos Sobral

E-mail: paola.sobral@gmail.com

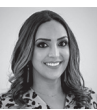

EDITOR IN CHIEF: Dulce Barbosa ASSOCIATE EDITOR: Ana Fátima Fernandes

Submission: $01-08-2020$

Approval: 07-18-2020

\begin{abstract}
Objective: To identify immediate transfusion reactions in elders hospitalized in a public hospital in the Federal District. Methods: This is an observational, retrospective, documental, and analytical research, with a quantitative analysis of 516 transfusions of packed red blood cells in elders hospitalized in the largest public hospital, who required blood components, from June to December 2017, through descriptive statistics. Results: The sample corresponded to $46.36 \%$ of the total number of transfusions in elders in the period. The mean age was 70 years old. There were adverse effects (reactions to the transfusion) in $12(2.3 \%)$ transfusions. Respiratory alterations (33.3\%) and fever (23.8\%) were the most common events. Conclusion: The incidence of reactions to the transfusion is below national and international rates, indicating probable undernotification, which could be associated to a lack of knowledge regarding its clinical manifestations and the lack of systematic monitoring of the transfusion. Descriptors: Transfusion Reaction; Blood Safety; Patient Safety; Blood Component Transfusion; Blood Component Transfusion; Quality of Health Care; Aged.
\end{abstract}

\section{RESUMO}

Objetivo: Identificar reações transfusionais imediatas em idosos internados em hospital público do Distrito Federal. Métodos: Pesquisa observacional, retrospectiva, documental e analítica, com análise quantitativa de 516 transfusões de concentrado de hemácias em idosos internados no maior hospital público demandante de hemocomponentes, de junho a dezembro de 2017, por meio de estatística descritiva. Resultados: A amostra correspondeu a $46,36 \%$ do total de transfusões em idosos no período. A mediana de idade foi de 70 anos. Houve manifestações adversas (reações transfusionais) em 12 (2,3\%) transfusões. Alterações respiratórias $(33,3 \%)$ e febre $(23,8 \%)$ foram os quadros mais comuns. Conclusão: A incidência de reação transfusional está abaixo dos parâmetros nacionais e internacionais, revelando provável subnotificação possivelmente relacionada ao desconhecimento das manifestações clínicas e à falta de acompanhamento sistemático da transfusão.

Descritores: Reação Transfusional; Segurança do Sangue; Segurança do Paciente; Transfusão de Componentes Sanguíneos; Qualidade da Assistência à Saúde; Idoso.

\section{RESUMEN}

Objetivo: Identificar reacciones transfusionales inmediatas en pacientes ancianos ingresados en un hospital público del Distrito Federal. Métodos: Investigación observacional, retrospectiva, documental y analítica, con análisis cuantitativo de 516 transfusiones de hematíes en pacientes ancianos ingresados en el mayor hospital público que requirió hemocomponentes, de junio a diciembre de 2017, utilizando estadística descriptiva. Resultados: La muestra correspondió al $46,36 \%$ del total de transfusiones en ancianos en el período. La mediana de edad fue de 70 años. Hubo manifestaciones adversas (reacciones transfusionales) en $12(2,3 \%)$ transfusiones. Los cambios respiratorios $(33,3 \%)$ y la fiebre $(23,8 \%)$ fueron las condiciones más frecuentes. Conclusión: La incidencia de reacción a la transfusión se encuentra por debajo de los parámetros nacionales e internacionales, lo que revela un probable subregistro posiblemente relacionado con el desconocimiento de las manifestaciones clínicas y la falta de seguimiento sistemático de la transfusión.

Descriptores: Reacción de Transfusión; Seguridad Sanguínea; Seguridad del Paciente; Transfusión de Componentes Sanguíneos; Calidad de la Atención Médica; Anciano. 


\section{INTRODUCTION}

With the transformation in its demographic profile, Brazil, since the, since the 1960 's, started to have a high number of elders, that is, 60-year-old or older people. The 19.6 million elders there in the country in 2010 will be nearly 67 million in 2050 , a relevant impact and a radical change in the age pyramid(1-3).

Due to the progressive and dynamic sequential changes in the aging process, which are often followed by functional disabilities, weaknesses, vulnerability, and by the increased longevity of the population, individuals not only have become more susceptible to noncommunicable diseases (such as cancer, cardiovascular and respiratory diseases), but also to acute events of these or other pre-existing conditions, being affected by functional limitations and hospitalizations ${ }^{(4-11)}$.

The hospitalization of elders may be a risk factor not only due to the diminution of their physiological capabilities of recovery, related to an increased potential of vulnerability and weakness which is inherent to aging, but also due to the impact of highly incident adverse events. These can result from many different interventions, among which is the therapeutic use of blood and its components ${ }^{(12-13)}$.

In modern hemotherapy, transfusion safety takes place when transfusion is based on clinical indications, to restore or maintain homeostasis. Its premises are the rational use of blood components, produced from the physical processing of whole blood or plasma, in addition to patient safety ${ }^{(14-15)}$.

Despite the fact that blood transfusions were correctly and timely prescribed, in a process that involves following good practices in all stages of the blood cycle - from the training of donors to the post-transfusion stage - not only it leads to undeniable benefits, but it also implies risks, such as the occurrence of transfusion reactions ${ }^{(16-21)}$.

Transfusion reactions are damage in varied degrees, related to blood transfusion, which may or may not result from mistakes in procedures or transfusion safety policies. They are classified according to the time clinical and laboratory manifestations associated to them take to appear, and can be: immediate, which appear during the transfusion or in up to 24 hours after the therapy started; or delayed, taking place 24 hours or more after the transfusion started ${ }^{(17)}$.

According to the international taxonomy of patient safety, standardized by the World Health Organization (WHO), transfusion reactions are considered adverse reactions when there is unexpected damage resulting from a justified treatment; or incidents involving harm to the patient (adverse event) ${ }^{(18)}$.

Hemovigilance, a relatively new process in transfusion safety, is paramount to the safety of the patient. It is defined as the group of surveillance procedures present from the collection of blood to the post-transfusion monitoring of the receptors. It aims to serve as a guide for actions to improve the safety in the use of blood and its components, and to prevent and mitigate transfusion events (among which, transfusion reactions), whether they are repeated, unexpected, undesirable, or even avoidable, through the capture and exam of information on the transfusion chain ${ }^{(17,22-23)}$.

In Brazil, hemovigilance started to be discussed in 2000, when there was a proposal for the creation of the Brazilian Network of
Sentinel Hospitals, regulated by the Resolution of the Collegiate Board (RDC) No. 51, from September 29, 2014, as one of the components of the National System of Hemovigilance (SNH) and as an active observatory of the performance of actions for the safety of transfusions ${ }^{(24-25)}$. Later, the SNH expanded to all health services that perform blood transfusions, with the advent of the System for Sanitary Surveillance Notifications (NOTIVISA), a computerized system made available by the National Agency of Sanitary Surveillance (ANVISA), to record the notifications of incidents involving products and services that are under the scope of sanitary surveillance, among which are blood and its components $^{(24-27)}$.

The Hemovigilance Report issued by ANVISA in 2015 showed that nearly $38 \%$ of the transfusion reactions recorded in 2014 took place in patients who were 60 years old or older. Additionally, the report raised the hypothesis that the rates of transfusion reaction in the general Brazilian population may be closer to 5 in every 1,000 transfusions than to the results measured then. That diverges from the French protocol, used as a parameter in Brazil, which estimates 3 transfusion reactions per 1,000 reactions ${ }^{(28-29)}$.

Despite the advances in transfusion safety, a Brazilian study ${ }^{(3)}$ showed that, even after a large initiative to raise the awareness and encourage the notification of events, focusing on "processes", "pharmacovigilance", "technovigilance", and "hemovigilance", the latter was the only one among these elements which did not see an increase in notifications, leading to the conclusion that transfusion reactions are still undernotified.

Although there have been efforts and evolutions in the hemovigilance system, the undernotification of these events is a reality that leads to risks to the health of the patient and prejudices the actions of the health teams ${ }^{(31)}$. However, suspected transfusion reaction events must be notified and evaluated by hemotherapy professionals to avoid acute and harmful reactions ${ }^{(32-33)}$.

During the literature search, no studies on the theme were found that dealt with the specific elements mentioned here. Considering the interest on the theme and on establishing hemovigilance information related to the quality of care with elder patients, identifying signs and symptoms of transfusion reactions in this public to encourage the improvement of records aimed at diminishing undernotification cases becomes relevant.

\section{OBJECTIVE}

To identify signs and symptoms of non-communicable immediate transfusion reactions related to the transfusion of packed red blood cells in elders hospitalized in a public hospital in the Federal District.

\section{METHODS}

\section{Ethical aspects}

To carry out the study, ethical aspects were respected, in accordance to the directives of Resolution No. 466 from December 12,2012 , from the National Council of Health (CNS). The Research Ethics Committee of the Foundation for Teaching and Researching Health Sciences (FEPECS) approved the conduction of the study. 


\section{Design, period, and place of study}

This is an observational, retrospective, documental, and analytical research, with a quantitative analysis guided by the STROBE guidelines. It was based on the verification of documents from the databases of the computerized system of the blood cycle of the central blood bank of the Federal District and from the electronic records used by the Public Health Network of the Federal District. Data collected refers to the use of packed red blood cells and to the search for adverse clinical manifestations related to the transfusion of this type of blood component, or to transfusion reactions in hospitalized elders. The study was conducted from June to December 2017 in the public hospital at the Federal District that requires and uses the highest number of blood components.

\section{Population; criteria of inclusion and exclusion}

The sample of the study was made up of 516 packed red blood cell transfusions involving hospitalized elders who were in accordance to all inclusion and exclusion criteria, among all elders hospitalized during data collection. The investigation included hospitalized elderly patients (60 year old or older), who received packed red blood cells from June to December 2017; it excluded those whose register/records could not be located in the computerized systems and those for whom there was no record of requests for using the blood component.

\section{Study protocol}

At first, the investigation collected data from all transfusions of packed red blood cells involving hospitalized elders that took place from June to December 2017, in the Federal District Hospital de Base (HBDF), a unit that is a part of the Rede Sentinela (the "Sentinel Network"). This information is present in the computerized system on the blood cycle from the Blood Bank Foundation of Brazil, the Sisthemo. It was made available by the institution including the name of the receptor, their date of birth, age at the time the transfusion took place, number of the medical records, sex, type of packed red blood cells, and date of transfusion.

Based on this list, the records of these patients were searched for in the "Patient Search"tool. The complete name and the birth date or medical records number, available in the electronic medical record system of the Health State Secretariat of the Federal District (SESDF), the Trakcare. Later, since the Sisthemo does not indicate whether the patients who received the packed red blood cells were hospitalized, the patients' hospitalization records were searched in the "List of Hospitalizations" — made up by the letter I followed by numbers automatically generated by the system -, according to the date of the blood transfusions.

After the hospitalization was selected, the records were accessed through the "PEP Manager", "Progress/Nursing Med Notes" tab. Based on the Trigger Tool methodology, which was standardized by the Institute for Healthcare Improvement $(\mathrm{IHI})^{(35)}$, the following search terms were initially used to identify blood transfusions and the eventual transfusion reactions: "packed", "red blood cells", "transfusion", "transfusion-related", "reaction", "CH". Later, the date in which the blood component was used was searched for, as indicated in the Sisthemo data, and well as the records of the request of the blood component, of the transfusion, and of immediate transfusion reactions, or to symptoms that could be related to the use of the packed red blood cells in the date of their administration and up to 24 hours later.

Once this data was surveyed, the information regarding the status of the patient (hospitalized, ambulatory, not-found), the type of assistance, origin, death, transfusion reaction, and clinical manifestations were organized in a spreadsheet in Microsoft Office Exce ${ }^{\circledast}$ for Windows ${ }^{\oplus}$. They were paired with the Sisthemo data for their evaluation.

\section{Analysis of results and statistics}

The descriptive analysis of the data regarding the measures of central tendency and dispersion, median and absolute and relative frequencies, was done in the program Statistical Package for the Social Sciences ${ }^{\circledast}$ (SPSS), version 20.0, for Windows ${ }^{\circledR}$.

\section{RESULTS}

In the period from June to December 2017, from the 3,435 blood red cell transfusions carried out in the hospital, 1,113 (32.4\%) were to elders. From these, 708 (63.6\%) were done in hospitalized elders, and for 185 of them (26.1\%) there was no register of the request or use of the blood component in the records of the patients, while 7 (0.9\%) did not have information that would enable one to locate the medical records of the patient. As a result, these cases were excluded from the study. Therefore, 516 blood transfusions, carried out in 258 patients, were analyzed.

The median age found was 70 years old, with a minimum of 60 and a maximum of 93 years. Table 1 shows the sociodemographic profile and the number related to the blood transfusions of patients included in the study. From the patients who received the packed red blood cells, it can be noted that most were men, and approximately half of them were from 60 to 69 years old. The 258 elder patients received a total of 516 transfusions of packed red blood cells. The median and mode were of one transfusion per receptor in the period analyzed.

Table 1 - Population and study variables, Brasília, Brazil, 2019 ( $n=258)$

\begin{tabular}{lc}
\hline Variables analyzed & $\mathbf{n}(\%)$ \\
\hline Sex & \\
Male & $148(57.4)$ \\
Female & $110(42.6)$ \\
Age group & \\
60 to 69 years & $128(49.6)$ \\
70 to 79 years & $90(34.9)$ \\
80 to 89 years & $34(13.2)$ \\
70 years or more & $6(2.3)$ \\
No. of blood transfusions & \\
1 blood transfusion & $145(56.2)$ \\
2 to 5 blood transfusions & $99(38.4)$ \\
6 to 9 blood transfusions & $12(4.6)$ \\
10 or more blood transfusions & $2(0.8)$ \\
\hline
\end{tabular}


Table 2 presents the distribution of blood components per ward that required them. It can be noted that the Emergency Room, the Hematology Ward, and the Nephrology Ward were responsible for nearly $50 \%$ of the requirements of packed red blood cells. Many sectors were included in other wards, such as the Intensive Care Unit - Trauma and Coronary Disease, Unit of Advanced Support to Trauma, Oncology Ward, General Surgery Ward, among others.

Table 2 - Federal District Hospital de Base units that requested packed red blood cells, Brasília, Brazil, $2019(n=516)$

\begin{tabular}{lc}
\hline Requesting ward & $\mathbf{n}(\%)$ \\
\hline Emergency Service & $146(28.3)$ \\
Hematology Ward & $52(10.1)$ \\
Nephrology ward & $49(9.5)$ \\
General Intensive Care Unit & $37(7.2)$ \\
Vascular Surgery Ward & $35(6.8)$ \\
Surgical Intensive Care Unit & $28(5.4)$ \\
Surgical Center & $26(5.0)$ \\
Gastroenterology Ward & $24(4.6)$ \\
Neurocardiovascular Center & $22(4.3)$ \\
Urology Ward & $20(3.9)$ \\
Other units & $77(14.9)$ \\
Total & $516(100)$ \\
\hline
\end{tabular}

At the time the blood components were indicated and used, the health care being offered to the patient was clinical in 356 (69.0\%) of transfusions, while in 160 (31.0\%) the care was surgical.

The explicit progress of anemia was one of the diagnostics in $10 \%$ of the cases in which the blood component was required in the Emergency Service. Neoplasms (31.2\%), hemorrhages (21.9\%), and fractures due to falls from one's own height (7.5\%) were the most common pre-transfusion diagnostics. Among the required transfusions of packed red blood cells, $19.2 \%$ were destined to patients in critical condition, palliative care, hemodialysis, and/ or oncology treatment.

Regarding the type of blood component required, 190 (36.8\%) corresponded to Filtered Packed Red Blood Cells, a component which had undergone leukoreduction - $99 \%$ reduction of leukocytes. Regarding the packed red blood cells in which the leukocyte and platelet layer is not removed, 169 (32.8\%) cases were recorded, while 157 (30.4\%) of cases used packed red blood cells with few leukocytes.

From the 516 transfusions of red blood cells, 12 (2.3\%) led to adverse clinical manifestations in the receptors of the packed red blood cells. The adverse signs and symptoms of the use of the blood component are represented in Table 3 and are related to the type of packed red blood cells used.

In table 3, it stands out that the most common adverse manifestations were associated with the respiratory system, being present in four transfusions, including shortness of breath associated with tachypnea, in two cases, and dyspnea in one, in the form of respiratory failure. Fever was present in five situations, both in isolation and associated to other signs and symptoms. Regarding the type of blood component, packed red blood cells were used the most, a total of seven transfusions, while filtered packed red blood cells and the low-leukocyte packed red blood cells were used in three and two cases, respectively.
Table 3 - Adverse symptoms related to the use of the packed red blood cells for blood transfusions - Brasília, Brazil, 2019 ( $n=516)$

\begin{tabular}{|c|c|c|c|c|}
\hline Transfusion & Patient & $\begin{array}{l}\text { Clinical } \\
\text { Manifestations }\end{array}$ & $\begin{array}{l}\text { Type } \\
\text { of BC }\end{array}$ & $\begin{array}{c}\text { Total of } \\
\text { transfusions/ } \\
\text { patient }\end{array}$ \\
\hline 1 & P1 & $\begin{array}{l}\text { Fever }+ \text { tachycardia }+ \\
\text { respiratory failure }\end{array}$ & FPRBC & 4 \\
\hline 2 & P2 & $\begin{array}{l}\text { Shortness of breath with } \\
\text { tachypnea }\end{array}$ & LLPRBC & 1 \\
\hline 3 & P3 & $\begin{array}{l}\text { Shortness of breath with } \\
\text { tachypnea + psychomotor } \\
\text { agitation }\end{array}$ & PRBC & 9 \\
\hline 4 & P4 & Fever & PRBC & 2 \\
\hline 5 & & Fever & PRBC & \\
\hline 6 & P5 & $\begin{array}{l}\text { Shortness of breath with } \\
\text { tachypnea + diminution in } \\
\text { the level of consciousness }\end{array}$ & PRBC & 2 \\
\hline 7 & P6 & $\begin{array}{l}\text { Shortness of breath with } \\
\text { tachypnea }\end{array}$ & FPRBC & 4 \\
\hline 8 & P7 & $\begin{array}{l}\text { Discomfort + asthenia + } \\
\text { tachycardia + dyspnea }\end{array}$ & LLPRBC & 6 \\
\hline 9 & P8 & Shivers & PRBC & 2 \\
\hline 10 & P9 & $\begin{array}{l}\text { Fever }+ \text { tremors + } \\
\text { hypotension }\end{array}$ & PRBC & 5 \\
\hline 11 & $\mathrm{P} 10$ & Fever + dyspnea & PRBC & 6 \\
\hline 12 & P11 & Respiratory difficulties & FPRBC & 2 \\
\hline
\end{tabular}

\section{DISCUSSION}

The median age in this study, carried out in a general hospital, was 70 years old, quite inferior to the findings of an American research which searched objective symptoms of transfusion reactions in the records of elders who received packed red blood cells, produced in a multi-level geriatric hospital, which found a median of 82 years $( \pm 9)$. However, the results of this research about the frequency of transfusions were corroborated by that study, which showed that $91 \%$ of patients received from one to two transfusions in the period (63\%, one transfusion; and $28 \%$, two transfusions) ${ }^{(36)}$.

More than $25 \%$ of the blood transfusions requested to the central blood bank and recorded in their screening system were not present in the constant progress of the medical records of the receptors. A review $^{(37)}$ that discussed the quality of the information in the records found that, among the irregularities found, there was a low number of complete records, leading to prejudice in the continuity of care.

When the $2.3 \%$ incidence of transfusion found in this study was compared to the consolidated data from ANVISA ${ }^{(38)}$, it was discovered that the result found here is below the one for the Federal District in 2014, which was of $4.6 \%$. Furthermore, the findings show that these occurrences were probably undernotified, since they are different from the Brazilian results, which are estimated to be 5 transfusion reactions for each 1,000 transfusions; and from the French parameter, which estimates a percentage of 3.03\% ${ }^{(38-39)}$.

Regarding the undernotification of transfusion reactions, Reis et al. ${ }^{(40)}$ found that therapeutic measures were only recorded in $36.7 \%$ of the receptors, who manifested a change in their vital signs during the transfusion of blood components, and the percentage of nurses with knowledge about hemotherapy practices 
was low in an Arabian and French study. Records showed that the absence of improvement or updates in transfusions, which limits the identification of reactions by the professionals and leaves gaps in the records of the actions taken due to transfusion reactions, can be factors that increase undernotification.

$30 \%$ of patients who had symptoms related to the use of the blood component had had multiple"poly-transfusions". According to the parameter established by Cruz et al. ${ }^{(41)}$, "poly-transfusion" takes place when a patient receives six or more units of packed red blood cells in three months. In the author's research, 3,044 patients in 12,904 were found to have undergone poly-transfusions, that is, a total of $23.6 \%$ of the population of the study.

Among the 146 transfusions requested by emergency care, anemia was clearly mentioned as one of the diagnostics at the time of request in $10 \%$ of cases. Beserra et al. ${ }^{(42)}$ described that anemia was the reason for $65.9 \%$ of transfusions, preceding its use due to hemorrhage (12.2\%). This data was corroborated by two other studies ${ }^{(43-44)}$ in which the percentages of requests due to low levels of hemoglobin and hemorrhage were, respectively, $66.6 \%$ and $22.6 \%$. When only the use of packed red blood cells was considered, the numbers were $78 \%$ and $20 \%$.

Packed red blood cells were the most used blood component in the cases in which there was reaction. This is a blood component whose processing does not involve filtration or reduction in leukocyte layer, a process that aims to prevent complications or reactions related to the use of allogeneic components, which may take place due to the exposure of the receptor to the leukocytes of the donor. The blood components without leukocytes are indicated, among other cases, for patients undergoing poly-transfusion or for those who have a history of two non-hemolytic fever reactions ${ }^{(14-15,45)}$.

Important clinical manifestations that the team monitoring the transfusion should look out for, regarding acute transfusion reactions, are: fever, shivers/tremors, pain in the site of the infusion of the blood component, hives, pruritus, erythematous plaques, skin rash, anaphylaxis, abdominal or side pain, diarrhea, thoracic pain, cough, bronchospasm, pulmonary rales, dyspnea, hypoxia, jugular distension, and pressure changes ${ }^{(17-46)}$. In this study, the most common signs and symptoms, directly related to the use of packed red blood cells, had two types: on one hand, respiratory alterations (such as dyspnea, shortness of breath coupled with tachypnea, and respiratory failure), and, on the other, fever. These types of symptom took place both in isolation and associated to other manifestations, corroborating the findings of other Brazilian studies ${ }^{(33,42)}$.

\section{Study limitations}

The fact that information related to the request and use of the blood component was incomplete or entirely absent from the records of the receptors, which was the case for $26.1 \%$ of the transfusions in the period, and, consequently, the adverse signs and symptoms that could be associated to the use of packed red blood cells, were a limitation of the study.

Considering that the focus was the infusion of the packed red blood cells in hospitalized elders, the absence of a sample of at least 1,000 blood transfusion also stands out, since this is the parameter adopted to predict the incidence of transfusion reactions.

\section{Contributions to the fields of Nursing, Health or Public Policy}

Since the literature available, especially in Brazil, is scarce, carrying out this study offers information that can fill in a gap in the scientific knowledge, by increasing the knowledge in this field. In addition, it highlights the need for further publication about post-transfusion hemovigilance in elderly patients, shows the need for actions targeted at the improvement of health information, in addition to strategies that encourage keeping complete records of transfusion reactions and train the professionals involved in the transfusion therapy about the recognition of mandatory actions. This applies not only to therapeutic actions, but also to operational ones, related to the communication and notification of these events.

Nurses are the professionals that, among many other attributions, essentially offer care to people almost incessantly, and, with regard to hemotherapy, make decisions, take actions, and, consequently, act in damage control in relation to the discomfort that results from transfusion reactions. Nurses are members of the health team responsible for administrating and/or supervising the administration of the transfusion, monitoring the infusion of the blood component, and acting in cases of adverse events.

Therefore, the standardization of effective and safe actions, strategies for hemotherapy and hemovigilance training, and the encouragement to records and to the communication of these events, may contribute to diminish the undernotification of transfusion reactions, to improve the quality of hemotherapy assistance, and increase the transfusion safety of the patient.

\section{CONCLUSION}

The results of this study made it possible to characterized the elder patients who received transfusions of packed red blood cells and to identify the incidence of adverse clinical manifestations regarding the transfusion. Also, through the research, the percentage of $2.3 \%$ adverse reactions was found regarding the use of the blood component, and the signs and symptoms most commonly associated to the use of the packed red blood cells were the changes in the respiratory system and fever, followed by tachycardia and shivers/tremors.

Therefore, it can be concluded that the incidence of immediate transfusion reactions in elders, associated to the use of packed red blood cells is below national and international parameters. It can be associated to the partial or total absence of information about transfusions and their follow-up; failures in the systematic monitoring of transfusion; and difficulties of the team in relating the adverse clinical framework to the use of blood component or to the lack of knowledge about the signs and symptoms of the transfusion reactions - the latter, potential determinants of the undernotification of the reactions.

\section{FUNDING}

The present work was supported by partnership signed between the Coordination for the Improvement of Higher Education Personnel - Brazil (CAPES) and Federal Nursing Council - Brazil (COFEN) - CAPES/COFEN Project No. 88881.137236/2017-01. 


\section{REFERENCES}

1. Miranda GMD, Mendes ACG, Silva ALA. Population aging in Brazil: current and future social challenges and consequences. Rev Bras Geriatr Gerontol. 2016;19(3):507-19. doi: 10.1590/1809-98232016019.150140

2. Presidência da República (BR). Lei no 10.741 , de $1^{\circ}$ de outubro de 2003. Dispõe sobre o Estatuto do Idoso e dá outras providências[Internet]. Diário Oficial da União 3 outubro 2003[cited 2019 Jul 1]. Available from: http://www.planalto.gov.br/ccivil_03/leis /2003/l10.741.htm

3. Simões CCS. Relações entre as alterações históricas na dinâmica demográfica brasileira e os impactos decorrentes do processo de envelhecimento da população. Rio de Janeiro: Instituto Brasileiro de Geografia e Estatística. Coordenação de População e Indicadores Sociais; $2016.113 p$

4. Rodrigues RAP, Fhon JRS, Pontes MLF, Silva AO, Haas VJ, Santos JLF. Frailty syndrome among elderly and associated factors: comparison of two cities. Rev Latino-Am Enferm. 2018;26:e3100. doi: 10.1590/1518-8345.2897.3100

5. Pereira AA, Borim FSA, Neri AL. Risk of death in elderly persons based on the frailty phenotype and the frailty index: a review study. Rev Bras Geriatr Gerontol. 2017;20(2):273-85. doi: 10.1590/1981-22562017020.160102

6. Duarte YAO, Nunes DP, Andrade FB, Corona LP, Brito TRP, Santos JLF, et al. Frailty in older adults in the city of São Paulo: Prevalence and associated factors. Rev Bras Epidemiol. 2018;21(Suppl 2):e180021. doi: 10.1590/1980-549720180021.supl.2

7. Leme DEC, Thomaz RP, Borim FSA, Brenelli SL, Oliveira DV, Fattori A. Survival of elderly outpatients: effects of frailty, multimorbidity and disability. Ciênc Saúde Colet. 2019;24(1):137-46. doi: 10.1590/1413-81232018241.04952017

8. Nunes BP, Batista SRR, Andrade FB, Souza Jr PRB, Lima-Costa MF, Facchini LA. Multimorbidity: The Brazilian Longitudinal Study of Aging (ELSI-Brazil). Rev Saúde Pública. 2018;52(Suppl 2):10s. doi: 10.11606/s1518-8787.2018052000637

9. Berlezi EM, Farias AM, Dallazen F, Oliveira KR, Pillatt AP, Korte Fortes C. Analysis of the functional capacity of elderly residents of communities with a rapid population aging rate. Rev Bras Geriatr Gerontol. 2016;19(4):643-52. doi: 10.1590/1809-98232016019.150156

10. Melo-Silva AM, Mambrini JVM, Souza Jr PRB, Andrade FB, Lima-Costa MF. Hospitalizations among older adults: results from ELSI-Brazil. Rev Saúde Pública. 2018;52(Suppl 2):3s. doi: 10.11606/s1518-8787.2018052000639

11. Permpongkosol S. latrogenic disease in the elderly: risk factors, consequences, and prevention. Clin Interv Aging. 2011;6:77-82. doi:10.2147/ CIA.S10252

12. Toffoletto MC, Barbosa RL, Andolhe R, Oliveira EM, Ducci AJ, Padilha KG. Factors associated with the occurrence of adverse events in critical elderly patients. Rev Bras Enferm. 2016;69(6):977-83. doi: 10.1590/0034-7167-2016-0199

13. Teixeira CC, Bezerra ALQ, Paranaguá TTB, Pagotto V. Prevalence of adverse events in elderly patients hospitalized in medical surgical unit Rev Baiana Enferm. 2017;31(3):e22079. doi: 10.18471/rbe.v31i3.22079

14. Ministério da Saúde (BR). Guia para o uso de Hemocomponentes. 2a ed. Brasília: Ministério da Saúde; 2015. 136 p.

15. Ministério da Saúde (BR). Portaria de Consolidação n 5, de 28 de setembro de 2017 [Internet]. Anexo IV. Diário Oficial da União 3 out 2017[cited $2019 \mathrm{Jul}$ 1]. Available from: http://portalarquivos2.saude.gov.br/images/pdf/2018/marco/29/PRC-5-Portaria-de-Consolida----o-n--5--de-28-de-setembro-de-2017.pdf.

16. Faquetti MM, Rosa RL, Bellaguarda MLR, Lazzari DD, Tholl AD, Moraes CLK. Percepção dos receptores sanguíneos quanto ao processo transfusional. Rev Bras Enferm. 2014;67(6):936-41. doi: 10.1590/0034-7167.2014670611

17. Agência Nacional de Vigilância Sanitária (ANVISA). Marco conceitual e operacional de hemovigilância: guia para a hemovigilância no Brasil. Brasília: ANVISA; 2015.74 p.

18. World Health Organization (WHO). Conceptual Framework for the International Classification for Patient Safety. Version 1.1. Final Technical Report January 2009 [Internet]. Geneva:WHO; 2010[cited 2019 Jul 1]. Available from: https://apps.who.int/iris/bitstream/ handle/10665/70882/WHO_IER_PSP_2010.2_eng.pdf?sequence=1

19. Grandi JL, Grell MC, Barros MO, Chiba AK, Barbosa DA. Frequency of acute transfusion actions in receptors of blood components transfusions. Vigil Sanit Debate. 2017;5(2):83-88. doi: 10.22239/2317-269x.00878

20. World Health Organization (WHO). Clinical Transfusion Process and Patient Safety [Internet]. Geneva: WHO; 2010 [cited 2019 Jul 1]. Available from: https://www.who.int/bloodsafety/clinical_use/who_eht_10_05_en.pdf?ua=1\#: :text= Patient\%20safety\%20in\%20blood\%20 transfusion,and\%20labelling\%20of\%20patient $\% 20$ blood.

21. Koh MBC, Lee YS, Chay J. Appropriate blood component usage. ISBT Science Series. 2011:6(2):249-256. doi: 10.1111/j.1751-2824.2011.01540.x

22. Agency for Healthcare Research and Quality. Facts and Figures 2009 - Table of Contents [Internet]. Rockville, MD: Healthcare Cost and Utilization Project (HCUP); 2012[cited 2019 Jul 1]. 99 p. Available from: https://www.hcup-us.ahrq.gov/reports/factsandfigures/2009/pdfs/FF_report_2009.pdf.

23. Bolton-Maggs $\mathrm{PH}$, Cohen H. Serious Hazards of Transfusion (SHOT) haemovigilance and progress is improving transfusion safety. Br. J. Haematol. 2013;163(3):303-314. doi: 10.1111/bjh.12547

24. Agência Nacional de Vigilância Sanitária (ANVISA). Manual Técnico de Hemovigilância - investigação das reações transfusionais imediatas e tardias não infecciosas. Brasília: ANVISA; 2007. 124 p. 
25. Ministério da Saúde (BR). Agência Nacional de Vigilância Sanitária. Boletim de Hemovigilância no 3. Brasília: ANVISA; 2010.20 p.

26. Ministério da Saúde (BR). Gabinete do Ministro. Portaria no 1.660, de 22 de julho de 2009. Institui o Sistema de Notificação e Investigação em Vigilância Sanitária - VIGIPOS, no âmbito do Sistema Nacional de Vigilância Sanitária, como parte integrante do Sistema Único de Saúde - SUS. Diário Oficial da União 23 jul 2009.

27. Conselho Nacional de Secretários de Saúde (CONASS). Vigilância em Saúde - Parte 2. Coleção Para Entender a Gestão do SUS. Brasília: CONASS; 2011.

28. Agência Nacional de Vigilância Sanitária (ANVISA). Boletim de Hemovigilância no 7 [Internet]. Brasil: ANVISA; 2015 [cited 2019 Jul 1]. Available from: http://portal.anvisa.gov.br/documents/33868/405222/Boletim+de+Hemovigil\%C3\%A2ncia+n\%C2\%BA+7/6e7fec ae-919c-4b5b-9723-b3552ea0295f

29. Sousa Neto AL, Barbosa MH. Immediate transfusion incidents: an integrative literature review. Acta Paul Enferm. 2012;25(1):146-150. doi: $10.1590 /$ S0103-21002012000100025

30. Silva JPB, Santos DC, Meireles HAS, Souza FM, Aguiar ASS, Melgaço TB, et al. Análise do sistema de notificações em vigilância sanitária NOTIVISA. Rev Para Med [Internet]. 2012 [cited 2018 Feb 8];26(4). Available from: https://www.researchgate.net/publication/236632885 ANALISE_DO_SISTEMA_DE_NOTIFICACOES_EM_VIGILANCIA_SANITARIA_-_NOTIVISA.

31. Frazão ACAY, Rolim GKL, Pantoja IP, Martins LF, Silva MJRB, Oliveira LF. Hemovigilância: utilização das ferramentas de gestão para a qualidade no processo transfusional. Rev Eletrôn Acervo Saúde. 2019;11(10):e642. doi: 10.25248/reas.e642.2019

32. Narvios AB, Lichtiger B, Neumann JL. Underreporting of minor transfusion reactions in cancer patients. MedGenMed [Internet]. 2004[cited 2019 Jul 1];6(2):17. Available from: https://www.ncbi.nlm.nih.gov/pmc/articles/PMC1395759/

33. Grandi JL, Grell MC, Areco KC, Barbosa DA. Hemovigilance: the experience of transfusion reaction reporting in a Teaching Hospital. Rev EsC Enferm USP. 2018;52:e03331. doi: 10.1590/S1980-220X2017010603331

34. Ministério da Saúde (BR). Resolução n 466, de 12 de dezembro de 2012 [Internet]. Brasília: Conselho Nacional de Saúde (CNS); 2012. Diário Oficial da União 13 jun 2013 [cited 2019 Jul 1]. Available from: http://bvsms.saude.gov.br/bvs/saudelegis/cns/2013/res0466_12_12_2012.html

35. Griffin FA, Resar RK. IHI Global Trigger Tool for Measuring Adverse Events (Second Edition). IHI Innovation Series white paper. Cambridge, Massachusetts: Institute for Healthcare Improvement; 2009.

36. Lubart E, Segal R, Tryhub N, Sigler E, Leibovitz A. Blood transfusion reactions in elderly patients hospitalized in a multilevel geriatric hospital. J Aging Res. 2014;2014:178298. doi: 10.1155/2014/178298

37. Ribeiro IAP, Elias CMV, Dourado MMGF, Campelo CL. Auditoria de enfermagem e a qualidade dos registros de prontuários. Rev FAESF [Internet]. 2018 [cited 2019 Jul 1];2(2):62-73. Available from: http://faesfpi.com.br/revista/index.php/faesf/article/view/45/43

38. Agência Nacional de Vigilância Sanitária (ANVISA). Relatório de Hemovigilância: Dados consolidados 2007-2014. Brasília: ANVISA; 2015c. 52 p.

39. Agence Régionale de Santé Île de France. Rapport annuel 2017 d'activité des coordonnateurs régionaux d'hémovigilanc [Internet]. Île de France. 2018 [cited 2019 Jun 21]. Available from: https://ansm.sante.fr/content/download/153399/2014835/version/2/file/Rapport Hemovigilance-2017.pdf

40. Reis VN, Paixão IB, Perrone ACASJ, Monteiro MI, Santos KB. Transfusion monitoring: care practice analysis in a public teaching hospital. Einstein (São Paulo). 2016;14(1):41-6. doi: 10.1590/S1679-45082016AO3555

41. Cruz RO, Mota MA, Conti FM, Pereira RAA, Kutner JM, Aravechia MG et al. Prevalence of erythrocyte alloimmunization in polytransfused patients. Einstein (São Paulo). 2011;9(2):173-8. doi: 10.1590/s1679-45082011ao1777.

42. Beserra MPP, Portela MP, Monteiro MP, Façanha MC, Adriano LS, Fonteles MMF. Reações transfusionais em um hospital Cearense acreditado: uma abordagem em hemovigilância. Arq Med [Internet]. 2014 Aug [cited 2019 Jul 24];28(4):99-103. Available from: http://www.scielo.mec. pt/pdf/am/v28n4/v28n4a02.pdf

43. Rocco JR, Soares M, Espinoza RA. Transfusão de sangue em terapia intensiva: um estudo epidemiológico observacional. Rev Bras Ter Intensiva. 2006;18(3):242-50. doi: 10.1590/S0103-507X2006000300005

44. Volpato SE, Ferreira JS, Ferreira VLPC, Ferreira DC. Red blood cells transfusion in intensive care unit. Rev Bras Ter Intensiva. 2009;21(4):391-7. doi: 10.1590/S0103-507X2009000400009

45. Governo do Distrito Federal. Secretaria de Estado de Saúde. Protocolo Transfusional - Indicação de Hemocomponentes. Brasília: Comissão Permanente de Protocolos de Atenção à Saúde da SES-DF - CPPAS; 2018. 45 p.

46. Souza GFR, Nascimento ERP, Lazzari DD, Böes AA, Bertoncello KC. Good nursing practices in the intensive care unit: care practices during and after blood transfusion. Rev Min Enferm. 2014;18(4):947-54. doi: 10.5935/1415-2762.20140069 